\title{
Application of the CSR guidelines to improve the working environment
}

\author{
Adam Górny ${ }^{*}$ \\ Poznań University of Technology, Faculty of Engineering Management, Chair of Ergonomics and \\ Quality Management, ul. Strzelecka 11, Poznań, Poland
}

\begin{abstract}
The continuous growth of business organizations is critical for their survival on competitive markets. To ensure such growth, undertakings need to identify areas for improvement and effectively deploy improvement measures with a view to ultimately increasing their company's value. One key area of improvement are working conditions in the working environment of employees. The assurance of employeefriendly working conditions that translate into working comfort constitutes part and parcel of the effort to facilitate the effective performance of work. Once CSR guidelines are incorporated into the process, the measures gain in effectiveness helping to enhance company value. The article identifies some of the aspects of managing working conditions - on the basis of CSR guidelines - that are vital for corporate performance. More specifically, such aspects include ways to facilitate the performance of occupational tasks by workers.
\end{abstract}

\section{Introduction}

The growth and improvement of enterprises depends crucially on a number of internal and external factors, including those that affect organizations' ability to ensure occupational safety. Ensuring such safety, in its turn, hinges in part on providing a worker-friendly environment. One prerequisite for ensuring such an environment is compliance with applicable standards and the satisfaction of relevant stakeholder expectations [1]. To achieve the above, organizations need acurately to identify such standards and expectations and undertake measures designed to improve the working environment.

Due to the complexity of the above task, it is advisable to resort to concepts for improving company operations and ultimately boosting the market standings of organizations [2].

One concept that has grown highly popular in today's world and that is utilized by a growing number of enterprises seeking permanently to secure an excellent competitive position is corporate social responsibility (CSR) [1]. By adopting the principles of corporate social responsibility, companies stand to benefit all concerned parties. Their success in doing so is predicated on acting consistently with CSR guidelines in all aspects of their activities.

\footnotetext{
${ }^{*}$ Corresponding author: adam.gorny@put.poznan.pl
} 
The aim of the study is to identify all areas that need to be recognized as crucial for the harmonious growth of business organizations. The discussion that follows is a literature review supplemented with observations generated through research. The study highlights possible applications of CSR guidelines in identifying such working-environment-related requirements as need to be satisfied to ensure the effective functioning of enterprises.

\section{Guidelines for shaping working environment}

In order to ensure safe and healthy working conditions, organizations need to meet certain standards that relate to the working environment and are designed to keep employees in good health [3]. This should be viewed as a fundamental duty of employers and one that enables them to prevent any negative impacts being brought to bear on their workers. Described more broadly, an organization's success in achieving the above goal is critical for obtaining the desired economic benefits $[4,5]$.

A safe working environment is a sine qua non condition for having organizations deliver on manufacturing and service-related objectives [6]. Such efforts can only be effective if the concerned organizations account for all environmental aspects that affect the functioning of humans in the working environment [7]. A worker-friendly working environment should be viewed as a safety concern. The importance of such an environment is tied to the role workers play in creating their company's competitive advantage $[8,9]$. Workers are key to ensuring operating effectiveness and, as such, should be provided with a working environment in which they can function efficiently. In view of CSR guidelines, such requirements should be extended to ensuring an adequate quality of life in the working environment. The achievement of proper quality of life in a working environment entails certain tradeoffs between technical, economic, organizational and social pursuits $[1,6]$.

The focus on providing a worker-friendly environment must not be reduced to that on working conditions alone. The effort must incoporate all worker accomodations to ensure the proper functioning of workers in their organizational and technical environment and to recognize the very nature of workers' needs [10]. The successful incorporation of organizational and technical solutions that relate to working conditions and are consistent with worker expectations, should extend to [11]:

- Physical working conditions, complete with physical factors (machines and devices, auxiliary equipment, work rooms), environmental parameters (lighting, temperature, noise, mechanical vibrations, radiant energy) as well as organic and inorganic chemical agents (vapors, gases and aerosols),

- The organization of work, including the assignment of responsibilities, the distribution of working time and the choice of worker performance methods,

- The economic factors that underpin the performance of work,

- Social working conditions characterized by social relations.

Furthermore, to establish a working environment that is consistent with worker needs, organizations need to embrace ergonomic requirements [12, 13]. Such requirements are traditionally expressed through ergonomic norms and standards that can be equated with ergonomic criteria. They pertain to what is referred to as the human factor and what is viewed as a contributor to the creation of economic value in an enterprise. No company that ignores this factor will be able to embrace state-of-the-art enterprise development concepts [6]. Ergonomic requirements may well be considered an integral part of working environment guidelines. Measures consistent with such requirements aim to optimize human loads in the working environment. This is accomplished by designing a working environment in which no workers are forced to bear unacceptable workloads. 


\section{Guidelines for shaping CSR}

\subsection{Nature of the implementation of CSR guidelines}

Corporate social responsibility (CSR) is a corporate growth concept that is essential for the economy. The concept is employed by companies seeking to secure a lasting competitive advantage $[2,14]$. CSR promotes voluntary efforts to strike a balance between economic, environmental and social aspects of company operations and its relationships with all stakeholders $[15,16]$.

CSR has gained significance in recent years, especially where international commitments are made concerning the functioning of workers and organizations in specific environments. The appreciation of CSR is commonly driven by the desire to find new trends and requirements (mostly for intangible factors) that may increase the value of companies by improving their reputations in the environment [1]. The recognition of the crucial role played by CSR in company performance stems from the potential benefits to be gleaned by all stakeholders [17]. To secure such benefits, organizations need to satisfy the expectations of entities that affect their functioning, not least those that concern safe working conditions [6].

The requirements designed to ensure occupational safety include working environment criteria which, if met, will balance the expectations of the concerned individuals (the workers) with those of enterprise owners (employers) [3]. By providing workers with a friendly work setting, organizations facilitate their effective performance. Thus, one can assume that the impact of environmental factors on the performance of work is a significant criterion for assessing the compliance of environments with requirements that, when satisfied, will enable workers to effectively perform their duties.

\subsection{Application of CSR guidelines to shape the working environment}

Corporate social responsibility requirements are increasingly associated with strategic management guidelines [15]. CSR requirements call upon organizations to undertake various measures, among them create a friendly working environment, which constitutes a crucial precondition for achieving desired outcomes [11].

A significant part of a worker-friendly working environment is to enable workers to function properly and mitigate any adverse consequences and impacts of ongoing changes. Note also that a socially responsible organization should not only fulfill relevant requirements and established expectations but also exceed them [6].

Proper attention needs to be paid to those CSR guidelines relating to working environments that help increase worker satisfaction with working conditions $[18,19]$. A number of the guidelines that concern worker-friendly working environments can be found in the ISO 26000 standard [11]. Such guidelines are considered to be a key area of social responsibility. According to them, the organization should [11-13]:

- Adopt and uphold a worker-friendly working environment policy recognized as a key enabler of effective work performance,

- Adopt an appropriate industry-specific hierarchy of measures aimed at creating a working environment that will meet worker requirements and expectations,

- Assess and monitor risks associated with failures to ensure working conditions conducive to the effective functioning of workers,

- Protect workers from adverse workloads, in particular where working environment standards are not respected for any reason,

- Record and scrutinize all events that may adversely impact the working environment, 
- Record and scrutinize all events resulting from failures to ensure a proper working environment,

- Ensure that the working environment satisfies the needs of specific worker groups, including pregnant women, recent (breastfeeding) mothers, the disabled, people lacking proper experience and working juveniles,

- Provide all employees with the same working environment, regardless of the work they do and their employment status,

- Eliminate all hazards in the working environment, including psychosocial,

- Provide all employees with up-to-date, complete and accurate information on the state of their working environment,

- Provide all employees with opportunities to speak out on the working environment, including any necessary improvements,

- Ensure that workers will only perform work if provided with a working environment that meets all legal and other requirements pertaining to worker safety,

- Refrain from disciplining any workers whose behaviors are triggered by the incompatibility of their working environment with relevant standards as long as such incompatibility does not result from their deliberate actions,

- Enable workers to consult competent external bodies regarding working environment issues,

- Enable workers to engage in efforts aimed at improving the working environment,

- Enable workers to report working-environment non-conformities to competent external bodies.

Tasks implemented by the employer, related to the requirements resulting from the CSR guidelines are presented in Tab. 1 .

Table 1. Measures taken to manage the working environment in pursuance with CSR guidelines.

\begin{tabular}{|l|l|}
\hline $\begin{array}{l}\text { Area of requirements } \\
\text { laid down in CSR } \\
\text { guidelines }\end{array}$ & \multicolumn{1}{|c|}{ Measures to be taken to meet requirements } \\
\hline $\begin{array}{l}\text { Raising worker } \\
\text { awareness }\end{array}$ & $\begin{array}{l}\text { - Ensure better understanding of the nature of issues by all workers in } \\
\text { the organization, including all levels of management, } \\
\text { - Ensure an understanding of the benefits and impacts of measures, } \\
\text { - Adopt recommended procedures by which engagement and } \\
\text { understanding should emanate from top management, } \\
\text { - Identify organizations adopting relevant measures on an ongoing basis } \\
\text { and use them as an example of potential benefits, } \\
\text { - Ensure that all parties (stakeholders) engage in the achievement of } \\
\text { desired outcomes, } \\
\text { - Ensure that existing knowledge and skills are properly utilized and/or } \\
\text { that additional knowledge and skills are acquired, } \\
\text { - Implement changes to help the organization secure new or enhance } \\
\text { existing benefits in its operations. }\end{array}$ \\
\hline $\begin{array}{l}\text { Setting a course to be } \\
\text { followed by } \\
\text { organization }\end{array}$ & $\begin{array}{l}\text { - Set a clear course of action towards the achievement of desired effects } \\
\text { by making specific, clear and concise commitments to respect working } \\
\text { environment standards and facilitate the creation of a proper } \\
\text { environment, } \\
\text { - Incorporate working-environment issues into the organization's } \\
\text { strategy and recognize them as a vital part of management, } \\
- \text { Incorporate adequate perception of working environment standards } \\
\text { into the organization's rules of conduct, } \\
- \text { Give working environment standards a high priority among the } \\
\text { organization's objectives and strategies. }\end{array}$ \\
\hline
\end{tabular}


Table 1 (cont.). Measures taken to manage the working environment in pursuance with CSR guidelines.

\begin{tabular}{|c|c|}
\hline $\begin{array}{c}\text { Area of requirements } \\
\text { laid down in CSR } \\
\text { guidelines }\end{array}$ & Measures to be taken to meet requirements \\
\hline $\begin{array}{l}\text { Incorporate the } \\
\text { requirements in } \\
\text { question into overall } \\
\text { structure of } \\
\text { management }\end{array}$ & $\begin{array}{l}\text { - Continually assess the impact of decisions on the state of the working } \\
\text { environment, } \\
\text { - Check any procedures and processes in place for impact on the } \\
\text { working environment, } \\
\text { - Mitigate adverse impacts of actions on the state of the working } \\
\text { environment; ensure that only actions whose adverse impact is limited } \\
\text { are selected, } \\
\text { - Continually identify resources necessary for creating a proper working } \\
\text { environment. }\end{array}$ \\
\hline
\end{tabular}

Source: Own work based on ISO 26000.

\section{Benefits derived from incorporating CSR guidelines in working environment improvement}

The incorporation of CSR principles into an organization's strategy will contribute to increasing its social capital [6]. Such capital makes it possible to achieve the desired goals by ensuring cooperation. Increase of capital to ensuring the sustainable development of the company.

The important aspect of improvement aimed at ensuring sustainable development is to effectively create a proper environment [14].

The effectiveness of such efforts can be assessed in terms of working comfort and specifically the ability to ensure the good health and well-being of workers. All of the above may be viewed as the satisfaction of the identified needs of the internal clients of an organization's processes [8]. The measures taken to achieve such conditions should include:

- Assessments of the potential implications of taking or not taking specific actions,

- Assessments of worker interest in specific issues,

- Identification of worker expectations regarding appropriate measures and their impacts.

It is possible to indicate the relationship between improving the conditions of human functioning and the increase of work efficiency. Such benefits allow organizations to develop a competitive advantage and dominate markets. Table 2 summarizes some of the most common measures taken in pursuance with the corporate social responsibility model in the field of working environment, allowing business organizations to benefit from increased operating efficiency.

It should be noted that a key factor for success in achieving the goals specified in Table 2 is the incorporation of working environment goals into the structure of management and decision making concerning the achievement of an organization's objectives. It is equally vital to identify verifiable targets with a view to assessing progress in meeting requirements. Such an assessment may involve the weighing of the required time and costs against the potential benefits of organizations. Having recognized that people are their biggest assets, organizations should note that the physical and psychosocial determinants of work performance affect both productivity and job satisfaction. Therefore, the creation of a proper working environment should be recognized as particularly important for ensuring an organization's success. By embracing CSR guidelines, organizations will bring to the 
forefront any requirements that are particularly vital for ensuring desired benefits for the organization's business.

Table 2. Examples of actions taken to shape the working environment, contributing to the improvement of working conditions.

\begin{tabular}{|c|c|}
\hline $\begin{array}{l}\text { Evaluation criterion of } \\
\text { requirements } \\
\text { compliance }\end{array}$ & Actions compliant with social responsibility \\
\hline $\begin{array}{l}\text { Communication to notify } \\
\text { employees about the } \\
\text { possibilities and needs in } \\
\text { terms of work conditions }\end{array}$ & $\begin{array}{l}\text { - All concerned persons notified on hazards at their workstations as } \\
\text { prescribed by law, } \\
\text { - Occupational health and safety hazards arising within organization and } \\
\text { at workstations examined and monitored, } \\
\text { - Particular attention given to vulnerable groups in view of the nature of } \\
\text { hazards. }\end{array}$ \\
\hline $\begin{array}{l}\text { Involvement of the } \\
\text { management in } \\
\text { improving providing } \\
\text { appropriate working } \\
\text { conditions }\end{array}$ & $\begin{array}{l}\text { - Proper conditions created to ensure that work can be performed in } \\
\text { dignity and that no benefits are derived from work-related abuse, } \\
\text { - Reducing the negative effects of implemented activities, } \\
\text { - Employer refrains from shunning its legal responsibilities towards } \\
\text { workers, } \\
\text { - Occupational health and safety policy formulated, implemented and } \\
\text { maintained in keeping with the principle that strict safety rules, shaping } \\
\text { a friendly work environment and company operations complement each } \\
\text { other, } \\
\text { - Action taken to eliminate psychological and social hazards at the work } \\
\text { place contributing to stress and illnesses. }\end{array}$ \\
\hline $\begin{array}{l}\text { Occupational health and } \\
\text { work environment } \\
\text { shaping education } \\
\text { offered to an extent } \\
\text { reflecting the nature of } \\
\text { work and worker needs }\end{array}$ & $\begin{array}{l}\text { - All workers offered proper training accordingly to their needs, } \\
\text { - Access provided to accurate up-to-date information on the measures } \\
\text { taken to improve the possibility of work performance, } \\
\text { - All workers at any stage of employment provided opportunities to } \\
\text { improve their skills, hands-on and theoretical training and career } \\
\text { advancement opportunities on equal non-discriminatory terms. }\end{array}$ \\
\hline $\begin{array}{l}\text { Motivating workers to } \\
\text { behave properly, } \\
\text { distinguishing employees } \\
\text { who abide by safety rules }\end{array}$ & $\begin{array}{l}\text { - Workers put in a position where they can adhere to safety practices and } \\
\text { follow applicable procedures of performing the work, } \\
\text { - Rules of conduct and management systems rely on informed consent } \\
\text { and involvement of workers, } \\
\text { - Workers and supervisors free to discuss occupational safety and } \\
\text { motivate workers to promote occupational safety as they see fit. }\end{array}$ \\
\hline $\begin{array}{l}\text { Cooperation ensured } \\
\text { among workers, trust } \\
\text { maintained between } \\
\text { management and } \\
\text { workers and among } \\
\text { workers }\end{array}$ & $\begin{array}{l}\text { - All workers provided with equal growth opportunities, direct and } \\
\text { indirect discrimination eliminated from work practices, } \\
\text { - The significance of social dialogue for the organization and the } \\
\text { workers duly recognized, } \\
\text { - Workers, their representatives and the management involved in } \\
\text { promoting health and safety. }\end{array}$ \\
\hline
\end{tabular}

\section{Conclusion}

The incorporation of CSR guidelines in the operating strategies of business organizations addresses the need to find solutions and areas through which company value can be increased. By embracing CSR guidelines, companies increasingly ensure the growth of their organizations in multiple aspects, which translates into solid market positions. In order to adopt the principles of corporate social responsibility in their operations, organizations should define the rules of collaboration with both their internal and external partners. One 
critical sub-group of internal partners are a company's employees. Therefore, the measures taken should largely be guided by their well-understood needs, the ultimate goal being to enable them to function properly in the working environment.

Organizations wishing to take a broader approach to shaping the working environment in conformity with CSR guidelines need to understand that the successful delivery of proper working conditions is predicated on the satisfaction of worker needs and expectations. The end result of such actions should be the physical and personal growth of individuals reflecting a dynamic model of humans. This will render the concerned organizations more effective in their operations and provide them with a wide range of benefits.

\section{References}

1. W. Tao, B. Song, M.A. Ferguson, S. Kochhar, Public Relations Rev. 44(5), 667-680 (2018)

2. J.C. Sanclemente-Téllez, Spanish J. of Marketing - ESIC. 21 (supp. 1), 4-25 (2017)

3. S.L. Murray, M.S. Thimgan, Human Fatigue Risk Management (Academic Press, Cambridge, 2016)

4. E. Lambert, N. Hogan, J. of Applied Security Research. 4(4), 462-482 (2009)

5. Communication for Commission to the European Parliament, the Council and the European Economic and Social Committee Implementing the partnership for growth and jobs: Making Europe a pole of excellence on Corporate Social Responsibility. $\operatorname{COM(2006),~} 136$ final (Commission of the European Communities, Brussels, 2006)

6. A. Górny, Ergonomics aspects of CSR in system shaping the quality of work environment, In: P. Vink (Ed.), Advances in social and organizational factors, pp. 541-550 (CRC Press, Boca Raton, 2012)

7. B. Höber, H. von Korflesch, Firm internal innovation contests: Work environment perceptions and employees' participation (Springer Fachmedien, Wiesbaden, 2017)

8. A. Górny, Procedia Manufacturing. 3, 4700-4707 (2015)

9. M. Rembiasz, MATEC Web of Conferences. 94, 07009 (2017)

10. H. King, W. Bedale, Hazard Analysis and Risk-Based Preventive Controls: Improving Food Safety in Human Food Manufacturing for Food Businesses (Elsevier, Amsterdam, 2017)

11. ISO 26000, Guidance on social responsibility (ISO, Geneva, 2010)

12. E.O. Aksak, M.A. Ferguson, S.A. Duman, Public Relations Rev. 42(1), 79-81 (2016)

13. J.A. Bernal-Conesa, A.J. Briones-Peñalver, C. De Nieves-Nieto, European J. of Management and Business Economics. 25(3), 121-132 (2016)

14. S. Shorrock, C. Williams, Human factors and ergonomics in practice: Improving system performance and human well-being in the real world (CRC Press, Boca Raton, 2016)

15. A. Zunjic, Ergonomic design and assessment of products and systems (Nova Science Publishers, Inc., New York, 2017)

16. P. Hąbek, R. Wolniak, Procedia - Social and Behavioral Sciences. 220, 115-123 (2016)

17. A. Górny, Management. 18(1), 43-57 (2014)

18. C.R. Baker, Corporate social responsibility (CSR): Practices, issues and global perspectives (Nova Science Publishers, Inc., New York, 2018)

19. J.J. du Plessis, U. Varottil, J. Veldman, Globalisation of corporate social responsibility and its impact on corporate governance (Springer, Berlin, 2018) 